\title{
Masalah Pembelajaran Pembuktian Matematika bagi MAHASISWA DI INDONESIA
}

\author{
Learning Problems of Mathematical Proof for Students in \\ INDONESIA
}

\author{
Indra Siregar
}

STKIP Sebelas April Sumedang

Sumedang, Jawa Barat, Indonesia

dracakep@yahoo.co.id

\begin{abstract}
Abstrak
Pembuktian matematika penting bagi mahasiswa matematika di perguruan tinggi, tetapi banyak mahasiswa matematika di perguruan tinggi Indonesia tidak bisa belajar pembuktian matematika dengan baik. Mereka merasa pembuktian matematika sangat sulit. Penelitian ini difokuskan pada mencari jawaban dari pertanyaan "mengapa mahasiswa matematika Indonesia tidak bisa belajar pembuktian matematika dengan baik?" dan "apa solusinya?". Upaya untuk menjawab pertanyaan ini sudah dilaporkan pada artikel Indra Siregar pada tahun 2015 dengan judul "Pembelajaran pembuktian matematik untuk pemula", tetapi peneliti menemukan beberapa informasi baru berdasarkan data dalam artikel itu. Peneliti menemukan bahwa mahasiswa matematika Indonesia tidak bisa belajar bukti matematis juga tidak hanya disebabkan oleh kemampuan logika matematika yang buruk dan kurangnya buku sumber untuk pemula, tetapi juga kurangnya pengalaman dalam menangani masalah matematika non rutin. Kita memiliki dua jenis solusi untuk memecahkan masalah ini, yaitu solusi jangka pendek dan solusi jangka panjang.
\end{abstract}

Kata Kunci: Pembuktian, Pembuktian Matematika, Pembelajaran Pembuktian Matermatika, Masalah Pembelajaran Pembuktian Matematika, Pembuktian Matematika untuk Pemula.

\begin{abstract}
Mathematical proof is important for mathematical student at college, but many mathematical student at Indonesian college can't learn mathematical proof well. They feel that mathematical proof is so difficult. The research is focused on looking for the answer of the question "why Indonesian mathematical college student can't learn mathematical proof well?" and "what is the solution?". The effort to answer the question have be reported on Indra Siregar's article in 2015 with the title "Mathematical proof learning for beginner", but the researcher found some new information based on the data in that article. The reseacher found that Indonesian mathematical college student can't learn mathematical proof well not only caused by bad logical mathematic ability and the lack of sources books for beginner, but the lack of experience on handling nonroutine mathematical problem. We have two kinds of solution to solve the problems, that is shortterm solution and long-term solution.
\end{abstract}

Keyword: Proof, Mathematical Proof, Mathematical Proof Learning, Mathematical Proof Learning Problem, Beginner Mathematical Proof.

\section{Pendahuluan}

Penelitian ini diawali dari masalah yang dikemukakan oleh Maya [1] yaitu pembuktian masih menjadi hal yang sulit bagi mahasiswa di Indonesia. Tentu hal ini akan membuat proses pembelajaran 
matematika mahasiswa terhambat dan cenderung gagal.

Penelitian ini dilakukan untuk menjawab masalah apa yang menyebabkan banyak mahasiswa yang sulit belajar pembuktian, serta apa solusi yang dapat kita gunakan untuk menyelesaikan masalah ini?

Sebelumnya telah diungkapkan dalam penelitian yang telah dipublikasikan oleh Indra Siregar [1] dalam artikel yang berjudul "Mathematical proof learning for beginner", bahwa kesulitan belajar mahasiswa pemula dalam pembuktian adalah lemahnya penguasaan logika matematika dan minimnya buku-buku pembelajaran pembuktian yang dikhususkan mahasiswa pemula. Setelah dikaji lebih lanjut, ada penyebab lain yang membuat banyak mahasiswa merasa kesulitan dalam pembuktian. Dalam artikel tersebut belum tergambar secara jelas solusi yang dapat digunakan menyelesaikan masalah itu.

\section{KAJIAN TEORI}

\section{A. Pembuktian}

Pembuktian adalah argumentasi logis yang membuktikan kebenaran dari sebuah pernyataaan. Jelas logika merupakan dasar dari sebuah pembuktian. [2]

\section{B. Masalah non rutin}

Dalam psikologi kognitif ada tiga istilah yang umum digunakan terkait bepikir yaitu equilibrium, disekuilibrium dan equlibrasi. Menurut Ormrod equilibrium adalah kondisi seseorang dimana seseorang tersebut dapat menafsirkan dan merespon peristiwa- peristiwa baru dengan menggunakan skema-skema yang sudah ada. Disequlibrium menurut Ormrod adalah kodisi sebaliknya yaitu kondisi seseorang perlu berusaha keras dalam memahami hal baru yang sedang diobservasi karena keterampilan dan pengetahuan yang dimiliki tidak memenuhi. Sedangkan equilibrasi menurut Ormrod adalah proses pergerakan dari equilibrium ke disequlibrium kemudian kembali lagi ke equlibrium. [3]

Equlibrium, disequlibrium dan equlibrasi dapat menjelaskan perbedaan bentuk dari soal matematika rutin dan nonrutin dalam penelitian ini. Ketika siswa hanya mengalami equilibrium saat menghadapi soal, maka soal tersebut soal rutin. Soal rutin ini memiliki ciri-ciri semua konsep yang dibutuhkan untuk menyelesaikan msalah tersebut sudah dimiliki oleh siswa. Ketika siswa mengalami ekulibrasi saat menghadapi soal, maka soal tersebut soal non rutin. Soal non rutin ini memiliki ciri-ciri tidak semua konsep yang diperlukan untuk menyelesaikan masalah sudah dimiliki siswa, siswa perlu berjuang keras untuk membangaun konsep yang tidak diketahui itu menggunakan konsep-konsep yang sudah dimiliki.

\section{Pemecahan Masalah [4]}

Menurut Polya cara memecahkan masalah terbagi atas empat fase. Fase pertama adalah memahami masalah. Fase kedua merencanakan rencana penyelesaian. Fase ke tiga adalah melaksanakan rencana. Fase ke empat adalah memeriksa kembali hasil pekerjaan. 


\section{Memahami masalah}

Menurut Polya, memahami masalah merupakan hal yang sangat mendasar. Siswa tidak akan penah bisa menyelesaikan masalah apapun, walaupun mudah, jika tidak bisa memahami masalah. Bahkan Polya mengatakan "it foolish to answer a questien that you do not undertand" untuk meng ekspresikan batapa bermasalahnya jika siswa tidak bisa memahami masalah dalam menghadapi soal.

Polya mengungkapkan banyak hal yang harus dilakukan dan dikuasai dalam memahami masalah. Agar siswa dapat memahami masalah, siswa harus dapat mengenal bahasa verbal yang ada dalam masalah. Selain itu siswa juga harus dapat mengajukan tiga buah pertanyaan yang dapat membantu memahami masalah. Pertanyaan tersebut adalah "apa yang tidak diketahui?", "data apa saja yang dimiliki?" dan "seperti apa kondisinya?". Siswa juga harus dapat mempertimbangkan bagian prinsip dari masalah dengan penuh perhatian, berulang kali, dan dari berbagai sisi sudut pandang hingga memenuhi kondisi yang diberikan.

2. Merencanakan penyelesaian

Menurut Polya, untuk dapat membuat perencanaan kita harus tau, paling tidak garis bersarnya, perhitungan atau kerangka yang harus dibangun terkait apa yang dicari. Jalan dari memahami masalah hingga mebuahkan rencana bisa panjang dan berliku. Kunci utama dalam mencari solusi masalah adalah ide. Ide bisa muncul seketika atau muncul setelah melakukan beberapa percobaan yang salah, atau bahkan bisa tidak muncul. Untuk melahirkan sebuah ide, harus memiliki banyak pengalaman dan pengetahuan sebelumnya. Mengingat saja tidak cukup untuk merancang rencana solusi. Kita harus mengetahui segalah, baik fakta atau konsep, yang terkait dengan masalah.

3. Melaksanakan rencana

Menurut Polya melaksanakan rencana lebih mudah daripada merancang rencana. Melaksanakan rencana hanya membutuhkan kesabaran. Kita tinggal mengikuti alur sesuai rencana. Namun, meski terlihat mudah tetapi tidak bisa diremehkan.

Polya juga mengingatkan bahawa tidak jarang kita lupa akan rencana yang telah dibuat. Itu terjadi jika kita memperoleh rencana solusi dari ide orang lain. Kita harus memastika ide yang mucul merupakan rancangan sendiri. Kita harus memastikan tiap tahap dilalui dengan sempurna dan lengkap.

4. Memeriksa kembali hasil pekerjaan

Menurut Polya, sebaik-baiknya rencana penyelesaian yang dirancang, setelititelitinya melakukan tahap-tahap sesuai rencana, tidak menutup kemungkinan ada yang terlewat dan terlupakan. Oleh karena itu memeriksa kembali merupakan hal yang wajib dilakukan dalam menyelesaikan masalah matematika. Aktivitas ini sebetulnya mudah, namun kita harus memiliki tingkat ketelitian yang baik. Memeriksa kembali merupakan tahap yang akan selalu mengingatkan kita bahwa kita adalah manusia. Memeriksa kembali juga merupakan ciri bahwa kita menyelesaikan masalah dengan jujur dan kerja keras. 


\section{Pembahasan}

Dalam Siregar telah diungkapkan temuan-temuan yang terkait pembuktian yang diperoleh dari analisis learning obstackel, baik analisis masalah belajar dari sisi epistimologi, maupun ontogenik/ didaktik. [1]

Dari kajian analisis masalah belajar dari sisi epistimologi yang dilakukan Siregar diperoleh bahwa mahasiswa masih bermasalah dalam logika matematika [1]. Dari 10 parisipan yang mengikuti tes analisis learning obstacel pembuktian, hanya empat orang yang mampu menjawab, namun salah dalam penggunaan logikanya. Dapat dilihat pada contoh gambar 1 dan gambar 2.

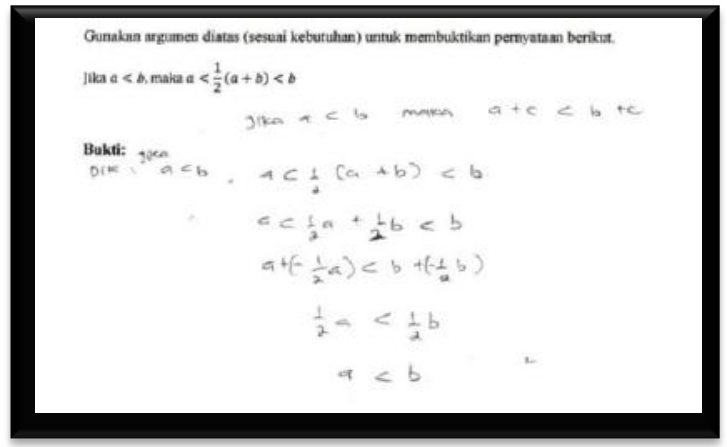

Gambar 1. Jawaban siswa yang tidak sesuai aturan logika matematika 1 [1]

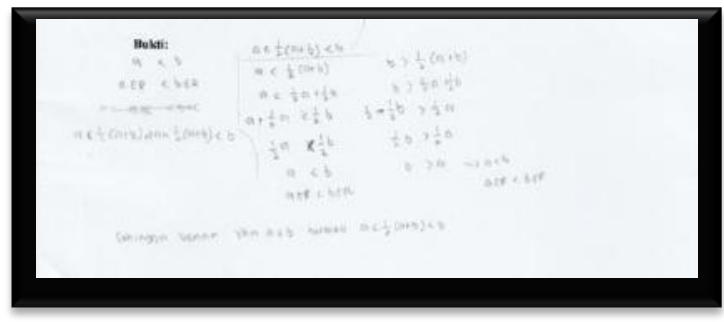

Gambar 2. Jawaban siswa yang tidak sesuai aturan logika matematika 2 [1]

Bila menurut pada aturan logika, pembuktiam langsung haris dimulai dari antesenden, dan berakhir di konsekuen, namun pada gambar 1 dan 2 telihat mahasiswa menjawab dimulai dari konsekuen.

Dari analisis learning obstacle dari sudut pandang ontogenis dan didaktis [1], ditemukan bahwa pembuktian dan logika matematika sudah mendapatkan pengalaman dasar sebelum masuk universitas, tepatnya di SMA. Namun mereka terpisah. Pembuktian yang dilakukian merupakan pembuktian sederhana di trigono metri contohnya pada gambar 3.

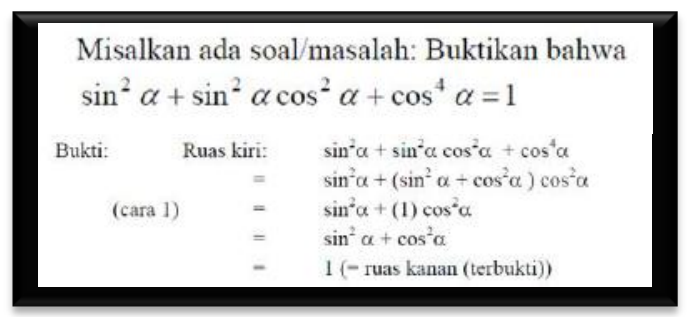

Gambar 3. Contoh pembuktian matematika di SMA (Krismanto dalam [1])

Artinya pembuktian di tingkat universitas seharusnya menjadi tempat untuk menggabungkan pembuktian dan logika matematika. . Jika digambarkan dapat membentuk diagram pada gambar 4 .

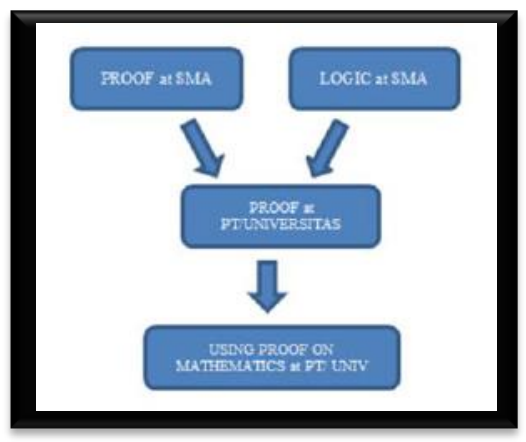

Gambar 4. Alur pembelajaran pembuktian dari SMA ke perguruan tinggi [1] 
Namun sayang, tahap penggabungan pengalaman tersebtu belum dapat dilkukan dengan maksimal. Kajian terhadap buku yang menyjikan konsep dasar pembuktian menggunakan logika matematika dalam bahasa Indonesia masih banyak yang hanya dapat dipahami oleh mahasiswa yang baru belajar pembuktian. Contohnya buku pada gambar 5 terlihat penggunaan logika matematika kurang begitu terlihat. Bukti pada gambar 5 hanya bisa dipahami oleh profesional.

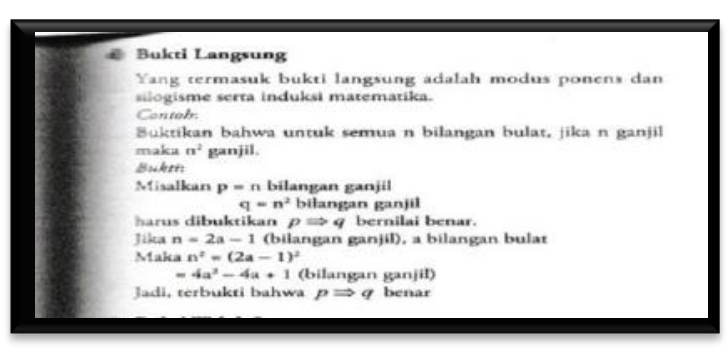

Gambar 5. Contoh pembuktian pada salah satu buku Indonesia [1]

Bandingkan dengan gambar 6, contoh bukti dalam buku pada gambar 6 menunjukkan contoh pembuktian yang menunjukkan dengan jelas penggunaan logika matematika di dalamnya. Bagi profesional, tentu contoh pembuktian pada gambar 6 sangat membosankan, tetapi sangat berarti bagi pemula. Namun jika pemula tersebut kurang baik kemampuan bahasa inggrisnya akan sulit pula dalam membacanya.

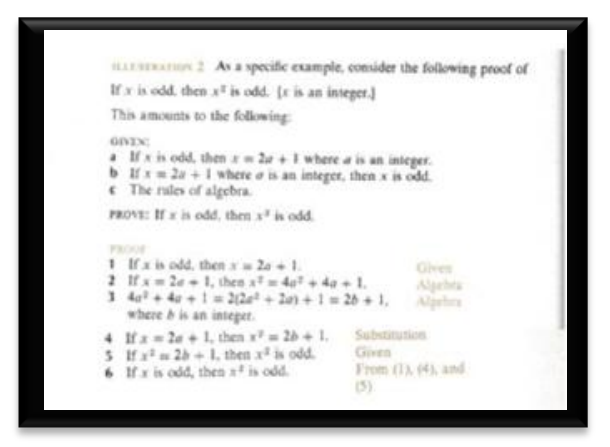

Gambar 6. Contoh pembuktian pada buku dari luar Indonesia [1]

Pengaruh kurangnya buku membuat mahasiswa tidak dapat belajar pembuktian dengan baik. Mahasiswa hanya bisa belajar poembuktian dari dosen yang pertemuannya terbatas dan sedikit.

\section{A. Pengembangan}

Perhatikan contoh pembuktian pada gambar 8 dan 9 .

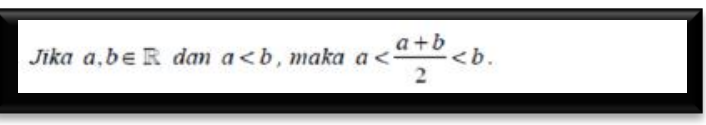

Gambar 7. Contoh soal yang dibuktikan (Riyanto dalam [1])

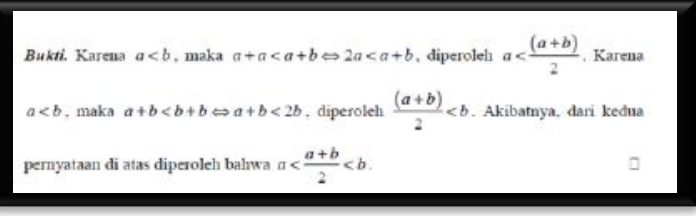

Gambar 8. Contoh pembuktian pada umumnya [5]

Jika kita jabarkan bukti pada gambar 8 , maka akan menjadi seperti pada gambar 9 . 


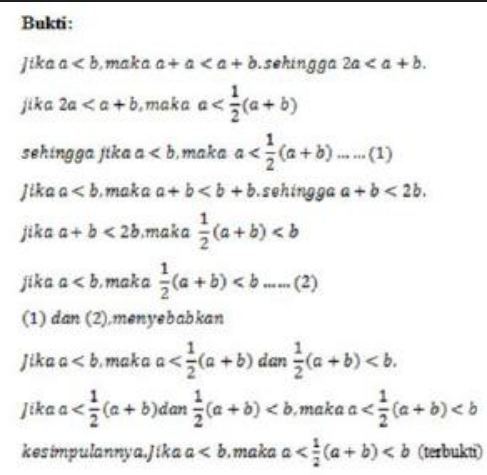

Gambar 9. Contoh pembuktian pada umumnya [5]

Jika pembuktian pada gambar sembilan dijabarkan sesuai aturan logika matematika, dan kata "maka" diganti dengan tanda " $\rightarrow$ " maka bisa jadi seperti pada gambar 10 .

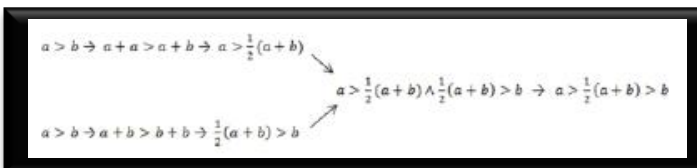

Gambar 10. Contoh alur pembuktian.

Dan jika penjabaran pembuktian seperti pada gambar 10 diperluas dan dikaitkan dengan teorema-teorema pembangunnya, maka akan terbentuk pola seperti seperti pada gambar 11 .

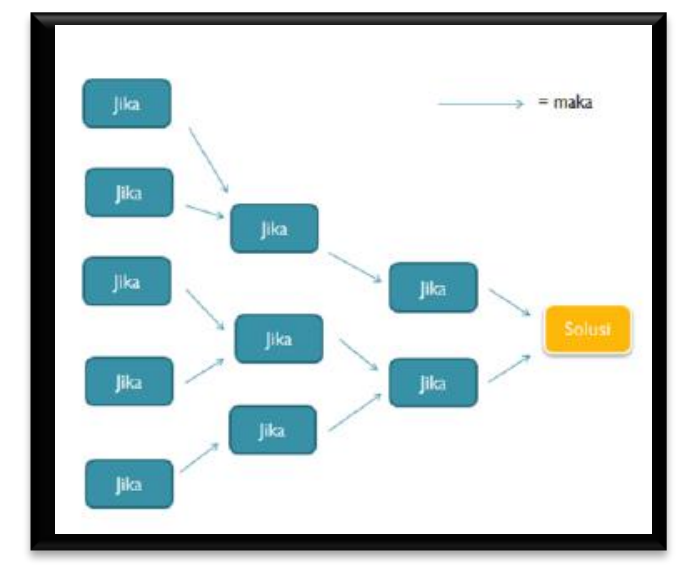

Gambar 11. Contoh alur pembuktian secara umum.
Dari pola pada gambar 11, jelas ada aktifitas analisis dan sintesis dalam pembuktian. Dan mengingat tidak ada yang sama dalam pembuktian, maka aktifitas analisis dan sintesis dalam pembuktian selalu terkait dengan hal baru. Sanga dekat dengan aktifitas pengerjaan soal non rutin disekolah.

Dalam The epistemological Learning Obstacle Analysis yang dilakukan oleh Siregar diungkapkan peserta yang mengikuti tes ada sepuluh orang mahasiswa, dua orang tidak memberikan jawaban, 4 orang menjawab tetapi salah, 4 orang menjawab benar namun tidak sesuai dengan teori logika matematika. [1]

Berdasarkan kajian lebih lanjut, empat orang yang menjawab namun tidak sesuai dengan teori logika memiliki jejak matematika yang cukup baik dimata kuliah lain, sedangkan enam orang lainnya tidak begitu bagus juga dalam matakuliah matematika lainnya. Hal ini sejalan dengan temuan adanya kaitan antara pebuktian dan soal nonrutin. Dapat dilihat lebih jelas pada tabel 1 .

Tabel 1.

Hubungan jawaban tes dan nilai matematika di matakuliah lain

\begin{tabular}{ccc}
\hline $\begin{array}{c}\text { Jumlah } \\
\text { mahasiswa } \\
\text { ikut tes }\end{array}$ & Jawaban tes & $\begin{array}{c}\text { Nilai } \\
\text { matematika di } \\
\text { matkul lain }\end{array}$ \\
\hline 4 & $\begin{array}{c}\text { Benar tapi tidak } \\
\text { sesuai }\end{array}$ & Baik \\
\hline 4 & Tidak benar & Sedang \\
\hline 2 & Tidak menjawab & Rendah \\
\hline
\end{tabular}

Dapat disimpulkan bahwa selain penguasaan logika yang baik, untuk dapat memahami pembuktian, perlu pengalaman bermatematika yang baik, terutama dalam menghadapi soal-soal nonrutin. 
Jika dikaitkan dengan soal nonrutin, siswa Indonesia memiliki masalah dalam menghadapi soal-soal nonrutin. Hasil TIMSS 2011 [6] dan PISA 2012 [7] menunjukkan Siswa Indonesia bermasalah dengan soal-soal non rutin.

Selain hasil PISA dan TIMSS, ada juga temuan - temuan hasil dari penlitian lain. Selama kurun waktu tahun 2012 hingga 2014, banyak penelitian dilakukan terkait pendidikan matematika di Indonesia pada jenjang SMP, SMA dan Perguruan Tinggi. Dari beberapa penelitian, ada tamuantemuan yang dapat menggambarkan dengan jelas permasalahan siswa dalam belajar matematika di Indonesia.

Dalam penelitian di jenjang SMP yang dilakukan oleh Anderson L. Palinussa pada tahun 2012 dengan judul "Peningkatan Kemampuan Berpikir Kritis dan Kreatif Matematis serta Karakter Siswa dalam Pembelajaran Matematika Realistik Berbasis Budaya", ditemukan bahwa: [8]

1. siswa kurang mampu dalam menentukan ide-ide baru,

2. siswa mengalami kesulitan dalam menghadapi soal tak lazim,

3. siswa sulit mengerjakan soal dengan cara lain,

4. siswa sulit dalam menganalisis masalah,

5. siswa kurang mampu mengkaitkan masalah matematika dengan konsep yang diperlukan dan mengkaitkan masalah dengan data yang relevan

Penelitian lainnya dilakukan oleh Nur Izzati pada tahun 2012 dengan judul "Peningkatan Kemapuan Komunikasi Matematis dan Kemandirian Belajar Siswa SMP Melalui Pendekatan Pendidikan Matematika Realistik". Dalam penelitian ini ditemukan bahwa: [9]
1. siswa memiliki kelemahan dalam membaca, ceroboh dan kurang teliti, serta masih sering salah dalam memahami soal,

2. siswa kurang mampu menggunakan bahasa yang tepat dalam merumuskan model, dan masih lemah dalam strategi pemecahan masalah,

3. siswa masih lemah dalam menginterpretasi ide-ide matematis yang diberikan dalam bentuk gambar dan menyajikan situasi matematis dengan gambar dan aljabar.

Penelitian lainnya dilakukan oleh Endang Wahyuningrum pada tahun 2014, dengan judul "Kemampuan Pemecahan Masalah, Komunikasi dan Disposisi Matematika Siswa SMP Melalui Strategi MEAs. Dalam penelitian ini ditemukan bahwa: [10]

1. siswa masih lemah dalam membuat model matematika dan memecahkan masalah yang tidak rutin,

2. siswa masih lemah dalam membuat model matematika SPLDV dalam bentuk grafik membuat soal cerita dari SPLDV yang diberikan serta meyelesaikannya.

Penelitian lainnya dilakukan oleh Heni Pujiastuti pada tahun 2014 dengan judul "Pembelajaran Inquiri Co-Operation Model untuk Meningkatkan Kemampuan Pemecahan Masalah, Komunikasi, dan Self-Esteem Matematis Siswa SMP”. Dalam penelitian ini ditemukan bahwa: [11]

1. siswa sulit dalam menulis ulang hal-hal yang ditanyakan dalam soal,

2. siswa belum terbiasa menghadapi soalsoal nonrutin. Siswa hanya mampu menghadapi soal rutin yang rumusrumusnya sudah jadi dan tetap,

3. kesalahan-kesalahan dalam menyelesaikan masalah tes kemampuan 
pemecahan masalah terjadi pada setiap indikator. Terutama pada indikator memeriksa dan menjelaskan kebenaran,

4. menyatakan suatu situasi atau ide matematis kedalam simbol matematis atau model matematis dan sebagian besar belum mampu menyelesaikan model matematis dengan baik.

Di tingkat SMA, ada penelitian yang dilakukan oleh Nahor Murani Hutapea pada tahun 2012 dengan judul "Peningkatan Kemampuan Penalaran, Komunikasi Matematis dan Kemandirian Belajar Siswa SMA melalui Pembelajaran Generatif". Dalam penelitian ini ditemukan bahwa: [12]

1. masih terlihat siswa merasa sulit dalam memahami soal cerita, dan membuat model matematika,

2. siswa masih sulit dalam menghadapi soal-soal nonrutin.

Penelitian di SMA lainnya dilakukan oleh Kartini pada tahun 2012. Penelitian tersebut berjudul "Peningkatan Kemampuan Berpikir Kritis dan Kreatif Serta Belief Matematis Siswa Sekolah Menengah Atas Melalui Pembelajaran Inkuiri Model Alberta". Dalam penelitian ini ditemukan bahwa: [13]

1. kemampuan evaluasi, Memecahkan masalah, membuktikan dan generalisasi masih sulit untuk ditingkatkan,

2. peningkatan pada aspek keluwesan dan kebaruan siswa masih rendah.

Penelitian di SMA lainnya dilakukan oleh Iskandar Zulkarnain pada tahun 2013 dengan judul "Kemampuan Pemahaman dan Komunikasi Matematis Siswa Dalam Pembelajaran Kooperatif Berbasis Konflik Kognitif'. Dalam penelitian ini ditemukan bahwa: [14]
1. siswa tidak menguasai pemahaman konseptual dan hanya sedikit pengetahuan prosedural,

2. ada beberapa hal yang harus dibenahi yaitu, pengetahuan konsep, pengetahuan prosedural dan kemampuan komunikasi ide dan gagasan,

3. tidak semua siswa mampu berpikiri analitis,

4. siswa belum sepenuhnya mampu memberikan argumentasi yang didasarkan pada prinsip dan konsep matematis.

Penelitian di SMA lainnya dilakukan oleh Hepsi Nindiasari pada tahun 2013 dengan judul "Meningkatkan Kemampuan dan Disposisi Berpikir Reflektif Matematis Serta Kemandirian Belajar Siswa SMA melalui Pembelajaran dengan Pendekatan Metakognitif. Dari penelitian itu ditemukan bahwa siswa sering melakukan kesalahan dalam menggambarkan suatu ilustrasi dari soal yang diminta. [15]

Penelitian di Perguruan Tinggi dilakukan oleh Yani Ramdani pada tahun 2013 dengan judul "Pembelajaran dengan Scientific Debate untuk Meningkatkan Kemampuan Komunikasi, Penalaran dan Koneksi Matematis Mahasiswa dalam konsep Integral". Dalam penelitian ini ditemukan bahwa mahasiswa masih sulit dalam: [16]

1. menyetakan peristiwa sehari-hari dalam bahasa atau simbol matematika,

2. menjelaskan ide, situasi dan relasi matematika secara tulisan dalam bentuk gambar, tabel, diagram, atau grafik.

3. memperkirakan jawaban dan proses solusi dan menggunakan pola dan hubungan untuk menganalisis situasi matematis. 
Dari semua temuan yang ada pada penelitian yang sudah dikemukakan diatas menunjukan bahwa pendidikan matematika di Indonesia memiliki masalah yang sama ditiap tingkat pendidikan, dari tingkat SMP hingga perguruan tinggi. Masalah-masalah tersebut adalah :

1. siswa masih lemah dalam menganalisa soal

2. siswa masih lemah dalam mengkaitkan hal-hal yang dibutuhkan untuk menyelesaikan masalah

3. siswa masih kesulitan dalam menggunakan simbol $\quad-$ simbol matematika

4. siswa/mahasiswa belum terbiasa menghadapi soal-soal nonrutin

\section{Penutup}

Dapat disimpulkan bahwa selain penguasaan logika yang buruk dan kurangnya buku sumber bagi pemula, banyaknya mahasiswa matematika di perguruan tinggi Indonesia kesulitan dalam belajar pembuktian matematika adalah kurangnya pengalaman mereke dalam menghadapi soal-soal non rutin.

Solusi untuk jangka pendek ini adalah solusi yang bisa diterapkan pada waktu dekat ini. Solusinya adalah mempersiapkan buku-buku tentang pembuktian dan buku-buku matematika yang memerlukan pembuktian matematika yang diperuntukkan khusus untuk mahasiswa yang baru belajar pembuktian. Pada buku-buku tersebut, bukti matematika ditulis segamlang mungkin. Contohnya bukti pada gambar 8 dapat diperjelas seperti pada gambar 9 .

Solusi untuk jangka panjang adalah solusi yang memerlukan waktu yang cukup lama, yaitu membuat siswa-siswa disekolah dari tingkat SD/sederajat hingga tingkat SMA/sederajat terbiasa dalam menghadapi soal-soal matematika non rutin.

\section{Daftar Pustaka}

[1] I. Siregar, Mathematical proof learning for beginner, Proceedings International Seminar on Mathematics, Science, and computer Science Education, FMIPA UPI, Bandung, 2015.

[2] Eductional Development Center. Making mathematics: Proof, (C) Education Development Center, 2002.

[3] Ormrod, 2008.

[4] G. Polya, How to solve it: a new aspect of mathematical method, New Jersey: Princeton University Press, 1957.

[5] S. Riyanto, Pengantar analisis real I (Introduction to real analysis I) Diktat Kuliah - Analisis. E-mail: zaki@mail.ugm.ac.id atau http://zaki.math.web.id, 2009.

[6] I. V. S. Mullis, dkk. TIMSS 2011 International Results in Mathematics. TIMSS \& PIRLS International Study Center, Lynch School of Education, Boston College Chestnut Hill, MA, USA and International Association for the Evaluation of Educational Achievement (IEA,) Amsterdam, Netherlands, 2012.

[7] OECD, PISA 2012 Results in Focus: What 15-year-olds know and what they can do with what they know, 2014.

[8] A. L. Palinussa, Peningkatan kemampuan berpikir kritis dan kreatif 
matematis serta karakter siswa dalam pembelajaran matematika realistik berbasis budaya, (Disertasi Program Doktor Sekolah Pascasarjana), Universitas Pendidikan Indonesia, Bandung, 2012.

[9] N. Izzati, Peningkatan kemapuan komunikasi matematis dan kemandirian belajar siswa smp melalui pendekatan pendidikan matematika realistik. (Disertasi Program Doktor Sekolah Pascasarjana), Universitas Pendidikan Indonesia, Bandung, 2012.

[10] E. Wahyuningrum, Kemampuan pemecahan masalah, komunikasi dan disposisi matematika siswa SMP melalui strategi MEAs, (Disertasi Program Doktor Sekolah Pascasarjana), Universitas Pendidikan Indonesia, Bandung, 2014.

[11] H. Pujiastuti, Pembelajaran inquiri co-operation model untuk meningkatkan kemampuan pemecahan masalah, komunikasi, dan self-esteem matematis siswa SMP, (Disertasi Program Doktor Sekolah Pascasarjana), Universitas Pendidikan Indonesia, Bandung, 2014.

[12] N. M. Hutapea, Peningkatan kemampuan penalaran, komunikasi matematis dan kemandirian belajar siswa SMA melalui pembelajaran generative, (Disertasi Program Doktor Sekolah Pascasarjana), Universitas Pendidikan Indonesia, Bandung, 2012.

[13] Kartini, Peningkatan kemampuan berpikir kritis dan kreatif serta belief matematis siswa sekolah menengah atas melalui pembelajaran inkuiri model alberta, (Disertasi Program Doktor Sekolah Pascasarjana), Universitas Pendidikan Indonesia, Bandung, 2012.

[14] I. Zulkarnain, Kemampuan pemahaman dan komunikasi matematis siswa dalam pembelajaran kooperatif berbasis konflik kognitif, (Disertasi Program Doktor Sekolah Pascasarjana), Universitas Pendidikan Indonesia, Bandung, 2013.

[15] H. Nindiasari, Meningkatkan kemampuan dan disposisi berpikir reflektif matematis serta kemandirian belajar siswa sma melalui pembelajaran dengan pendekatan metakognitif, (Disertasi Program Doktor Sekolah Pascasarjana), Universitas Pendidikan Indonesia, Bandung, 2013.

[16] Y. Ramdani, Pembelajaran dengan scientific debate untuk meningkatkan kemampuan komunikasi, penalaran dan koneksi matematis mahasiswa dalam konsep integral, (Disertasi Program Doktor Sekolah Pascasarjana), Universitas Pendidikan Indonesia, Bandung, 2013.

\section{Riwayat Hidup Penulis}

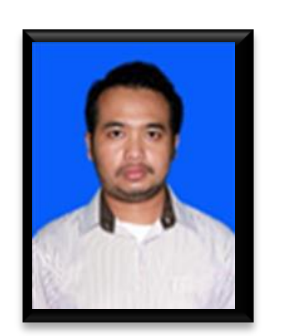

Indra Siregar M.Pd. Lahir di Cianjur, 28 Juni 1987. Staf pengajar di STKIP Sebelas April Sumedang. Studi S1 Pendidikan Matematika Suryakancaniversitas Suryakancana Cianjur, lulus tahun 2009. S2 Pendidikan Matematika Universitas Pendidikan Indonesia, Bandung, lulus tahun 2012. 